tion or loss taking place when the property was outside the taxpayer's control.

If the containers were not returned because of destruction, loss, or appropriation by customers, as the Tax Court found, then section 117(j) ought to have been applied. The court appears to have been unduly impressed with the statement in the Wichita case that, "Such a financial act creates income in the year in which it is done." Is it not rather the failure to return the containers that released the taxpayer from an obligation to pay out the deposits and thus gave rise to the income? Indeed, the Tax Court comes close to answering that question when it said that the rights the customer had in the deposit were "shattered with the bottle." "86a

Viewed in this light, the creation of such income appears to be more or less of a continuous process as the individual containers are broken, lost, or appropriated by customers to other uses. The action of the board of directors in transferring sums from the deposit liability account would then only be a problem of proper accrual accounting (and not a question of income production), the accuracy of which may or may not be supported by the facts in a particular case.

The result in the $N e h i$ case may possibly be explained simply as a failure of the petitioner to sustain the taxpayer's burden of proving the right to the benefit of the section. ${ }^{87}$ Otherwise, we might be able to define with more assurance the applicable limits of section $117(\mathrm{j})$ by including within its scope a situation involving an involuntary conversion or unreturned returnable containers. The case may be used as a precedent for denying relief to other taxpayers who suffer loss of property against which a deposit has been paid.

At least we remain assured that any attempted application of section $117(j)$ to a new or unique situation will meet with resistance from the Bureau.

Harlo L. Robinson

\title{
TORT LIABILITY OF AIR CARRIERS TO THEIR PASSENGERS
}

The phenomenal mechanical advances which have made the airplane a leading transportation instrumentality have also required creation of a new set of legal relations pertaining to air carriers and their passengers. At present few appellate courts have discussed the elements of this relationship; however, a multitude of trial court opimons and jury instructions exist which indicate judicial attitudes. It is the purpose of this comment to classify these materials and to extract from them the rules of tort liability which have so far been established for air common carriers. An effort has been made to use only those trial court instructions which have crystallized into widely accepted principles, and which are likely to be approved by the appellate courts.

The initial task in each case is to determine whether the operator is a

80a Supra note 84 at 8.

87 The importance of the fact finding function of the Tax Court should always be kept in mind. See Commissioner v. Scottish American Co., 323 U.S. 119 (1944). 
common carrier. This is necessary not only because a different standard of care is applied to private carriers, but also to establish the effect of insurance exemption clauses and the applicability of pertinent statutes. In performing this difficult task, the courts, in so far as possible, have carried over and applied as precedents cases decided for ground carriers. In general, an operator is a common carrier if "he holds out either expressly or by a course of conduct, that he will carry for hire, so long as he has room, [passengers or] the goods of all persons indifferently who send him goods to be carried." 1 No fixed routes or set schedules are required, ${ }^{2}$ nor need the carrier land at an airport different from the point of departure. ${ }^{3}$ Clearly within this classification are both scheduled and non-scheduled airlines. Difficulty is encountered, however, in determining the status of those operators, such as sight-seeing carriers, who have restrictions on the persons they will carry or the purposes for which they will hire. In this penumbra the decisions cannot be completely reconciled since the courts have taken different views of the effect of particular flight arrangements in determining the carrier's status. $^{4}$

\section{REQUIRED STANDARD OF CARE}

In the early years of aviation the primary emphasis of courts and legislatures was on fixing the liability of aviators for injuries to persons and property on the ground. As to these injuries the airplane was looked upon as a dangerous instrumentality, and operators were held absolutely liable for all damage resulting from their flights. "By the time mechanical developments were sufficient to justify utilization of the airplane for carrying passengers, this ultrahazardous activity notion had largely disappeared, and in their dealings with passengers the airpline operators were held to the same standard of care and liability as ground carriers. ${ }^{a}$ A good statement of the present duty was made in Allison v. Standard Air Lines, where the jury was charged that an air common carrier "is bound to exercise the highest degree of practical care and diligence and is liable for all matters against which human prudence and foresight might guard."7 A Massachusetts

1 Nugent v. Smith, 1 C.P.D. 19, 27 (1875), quoted in North American Acc. Inc. Co. $\checkmark$. Pitts, 213 Ala. 102, 105, 104 So. 21, 23 (1925), and Georgia Life Insurance Co. v. Easter, 189 Ala. 478,66 So. 514 (1914).

2 McCusker v. Curtiss-Wright Flying Service, 269 Ill. App. 502, 1933 U. S. Av. R. 105; Ziser v. Colonial Western Airways, 10 N. J. Misc. 1118, 162 Atl. 591 (1932).

3 Smith v. O'Donnell, 215 Cal. 714, 12 P.2d 933 (1932). The court applied Cat. Crv. Codz \$2168: "Everyone who offers to the public to carry persons, property or messages, excepting only telegraphic messages, is a conimon carrier of whatever he thus offers to carry."

4 Seaman v. Curtiss Flying Service, 1929 U. S. Av. R. 48 (sight-seeing operator not a common carrier); rev'd on other grounds, 231 App. Div. 867, 247 N. Y. Supp. 251 (1930). Accord: North American Acc. Ins. Co. v. Pitts, supra note 1; Brown v. Pacific Mut. Life Ins. Co, 8 F.2d 996 (5th Cir. 1925). But cf. Ziser v. Colomial Western Airways, supra note 2.

5 Conn. Laws 1911, c. 86, § 11, repealed by Conn. Laws 1925, c. 249, and Conn. Laws 1927, c. 324. Cf. Rochester Gas \& Electric Corporation v. Dunlop, 148 Misc. 849, 266 N. Y. Supp. 469 (1933).

6 For statutes so providing see text at note 47 infra.

71930 U.S.Av. R. 292 (S. D. Cal.), aff'd, 65 F.2d 668 (9th Cir. 1933). Accord: Conklin v. Canadian Colonial Airways, 1934 U. S. Av. R. 21, aff'd without opinion, 242 App. Div. 625, 271 N. Y. Supp. 1107 (1934); Smith v. O'Donnell, supra note 3 (applying CaL. CIv. Code \$2100: 
court, in comparing this standard with that of a private air carrier, stated that the degree of care required of a common carrier for hire is measurably greater than the law imposes on a private carrier for hire. ${ }^{8}$ By expressing this duty $m$ terms of degrees of care, the courts are simply emphasizing the fact that air common carriers have a great responsibility, and this responsibility is to be considered in the determination of what is reasonable conduct under the circumstances. ${ }^{9}$

One factor influencing the determination of whether the proper degree of care has been exercised is the peculiar nature of air travel. The airplane travels at high speed, and, unlike a train or bus, must continue that speed to remain aloft. This consideration is usually expressed by the courts as a caution that the degree of care required of the carriers need only be such as is consistent with the practical operation of the airplane..$^{10}$

Courts have recogmized that exercise of even the utmost care cannot free passengers from all the perils likely to be encountered in air travel. Carriers are therefore allowed to interpose the defenses of contributory negligence ${ }^{11}$ and assumption of risk. ${ }^{12}$ Contributory negligence has caused little trouble, since the majority of accidents occur during flight when little opportunity is offered the passenger to contribute to his injury through his own carelessness. Assuniption of risk, however, has produced some confusion.

The fact that carriers are not insurers of their passengers' safety means, of course, that they will not be held liable for accidents which could not have been avoided even by the exercise of the greatest care. ${ }^{13}$ The courts have usually expressed this by saying that such risks have been assumed by the passenger as an ordinary hazard of air travel ${ }^{14}$ hence, one of the most frequent defenses by the carrier is assumption of risk. ${ }^{15}$ Such labeling seems not to aid analysis, since in almost all cases ${ }^{16}$ the real question is whether the carrier could, by exercising the utmost care, have foreseen the danger and taken steps to avoid it. If it could not, there is no liability, absent $\dot{m}$ surer's status.

The burden of proving that the injury was due to the negligence of the

"A carrier of persons for reward must use the utmost care and diligence for their safe carriage, must provide everything necessary for that purpose, and must exercise to that end a reasonable degree of skill.").

8 Wilson v. Colonial Air Transport, 278 Mass. 420, 180 N. E. 212 (1932).

9 See Allison v. Standard Airlines, supra note 7; Prosser, TORTS 256-57 (1941).

${ }^{10} \mathrm{Law}$ v. Transcontinental Air Transport Inc., 1931 U.S.Av. R. 205 (E.D. Pa.) (jury instruction); Foot v. Northwest Airways Inc., 1931 U.S. Av. R. 66 (D. C.Minn) (jury instruction); Wilson v. Colonial Air Transport, supra note 8.

11 Ebrite v. Crawford, 215 Cal. 724, 12 P.2d 937 (1932); Curtiss-Wright Flying Service v. Williamson, '51 S. W.2d 1047 (Texas 1932).

12 Cohn v. United Air Lines Transport Corporation, 17 F. Supp. 865 (D. C. Wyo. 1937) ; Allison v. Standard Air Lines, supra note 7.

13 Courts often categorize such an accident as an act of God or an unforeseen event. Actually all these terms carry the same meaning.

14 Johnson v. Western Air Exp. Corp., 45 C.A.2d 614, 114 P.2d 688 (1941); Cohn v. United Air Lines Transport Corporation, supra note 12 ; Allison v. Standard Air Lines, supra note 7.

15 See, generally, cases cited supra notes 9 to 12 .

16 In State, Use of Beall v. McLeod (Super. Ct. of Baltimore 1932), 1932 U.S. Av. R. 94, the court charged the jury that a passenger assumed the risk of an obvious defect. This is proper-there was carelessness on the part of the carrier, but no duty to the passenger since he could be said to have consented. 
carrier is in varying degrees aided by the dactrine of res ipsa loquitur. A discussion of this problem and the different effects given it by the various jurisdictions is beyond the scope of this comment. ${ }^{16 a}$

\section{COMPLIANCE WITH THE REQUIRED STANDARD}

The basic elements of the conduct required of carriers were outlined by the courts without difficulty in the early cases establishing the standard of utmost care. The operator must provide a properly equipped airplane, skilled pilots, proper landing fields, ${ }^{1 T}$ complete maintenance for the aircraft, ${ }^{18}$ and adequate facilities for the gathering and transmission of weather data. ${ }^{19}$ Furthermore, the duty of protecting passengers is not limited to the flight itself. Passengers must be removed safely from the airplane to the ground, and must be guided clear of any revolving propellers which may block the path from airplane to hanger. ${ }^{20}$

The courts do not impose liability for injuries resulting from sudden storms and air turbulence which the carrier could not have anticipated. Frequently the reason given for failure to hold the carrier liable is that the passenger assumed the risk. ${ }^{21}$ That this involves a mistake in emphasis is illustrated by the cases where injury has been caused by failure of the passenger to fasten his seat belt. If the pilot should have foreseen the rough weather, the carrier is held for failure to warn passengers to fasten their belts. ${ }^{22}$ If under the circumstances turbulent weather could not have been predicted by the exercise of the required care, then it is said the passengers leave their belts unfastened at their peril. ${ }^{23}$ To put the result reached in the latter case in terms of assumption of risk is to evade answering the important question of whether it was negligent to fail to anticipate the danger.

When foreseeability of adverse weather was an issue in the earlier cases, the courts usually injected into their instructions a comment on the newness of air carriage. The obvious purpose was to call attention to the carrier's inexperience with the atmosphere's capricious behavior. ${ }^{24}$ This instruction is still used today, ${ }^{25}$ but its relevance has been greatly diminished. The kinds of atmospheric disturbances which can be said to be unexpected should be recognized as rapidly decreasing in number with the expansion of the carrier's knowledge.

\footnotetext{
16a For extensive discussion of the doctrine see McLarty, Res Ipsa Loquitutr in Air Line Passenger Litigation, 37 VA. L. REv. 55 (1951).

${ }^{17}$ Stoll v. Curtiss Flying Service, 1930 U.S.Av. R. 148 (jury instruction), af'd without opinion, 236 App. Div. 664, 257 N. Y. Supp. 1010 (1932) ; Boele v. Colonial Western Airways, 110 N. J.L. 76, 164 Atl. 436 (1933).

18 Kamienski v. Bluebird Air Service, 321 Ill. App. 340, 53 N.E.2d 131 (1944), appeal dismissed, 389 III. 462, 59 N. E.2d 853 (1945); State, Use of Beall v. McLeod, sutpra note 16. 19 Thomas v. American Airways, 1935 U.S. Av. R. 102 (S. D. Cal.).

20 Curtiss-Wright Flying Service v. Williamson, supra note 11.

21 Cases supra note 14.

22 Small v. Transcontinental \& Western Air, 96 C. A. 2d 408, 216 P.2d 36 (1950).

${ }^{23}$ Law v. Transcontinental Air Transport Inc., stipra note 10; Kimmel and Byrd v. Penna. Airlines Co., 1937 U.S.Av. R. 104 (D.C.D.C.); Parsley v. Mid-Continent Airlines, 1949 U.S. Av. R. 424 (D. C. Minn.).

24 Cohn v. Umited Air Lines Transport Corporation, supra note 12; and cases cited supra note 10.

${ }^{25}$ Small v. Transcontinental \& Western Air, supra note 22.
} 


\section{Pilot's Duty: Variation from Established Procedures}

The pilot, as agent of the carrier, must also exercise the utmost care for the safety of his passengers, and to that end must display the same skill and judgment generally possessed by pilots engaged in the same business. ${ }^{26}$ Extremely important in determining whether the pilot was negligent is his variation from the procedures adopted by the carrier for the conduct of its flights. Most of these procedures are adopted pursuant to various state and federal regulations, and deviations raise the problem of violation of statutes. ${ }^{27}$ Others, however, are based on the experience of carriers and pilots, who recognize that compliance is essential to safe flying. Although the latter procedures need not be recognized by the courts, and although observance of them may not in all cases constitute sufficient conformance to the required duty, they are usually accepted by the courts as an indication of what conduct is necessary to assure the safety of the passengers. ${ }^{2 s}$

The effect of failure to follow prescribed procedures was squarely before the New Jersey court in Ziser v. Colonial Western Airways. ${ }^{29}$ During a takeoff the pilot encountered engine trouble, made a right turn, and headed east, losing altitude. To avoid a burning dump he attempted to override a railroad, failed, and crashed into a car on the tracks. The court took into account the existence of a ground rule to the effect that planes whose route required a turn after taking off should inake the turn to the left, and stated:

The importance of obeying that rule, under the circumstances of this case is clear, for in case of a forced landing a left turn would bring the plane over the comparatively harmless swamp, while a right turn would carry it over railroad yards and tracks and the burning dumps as actually happened. It is said that the pilot was ignorant of this rule. If so the jury were entitled to consider that he should have informed himself of it, or that other agents should have informed him of it. In either event a charge of negligence in this regard comes back to the defendant.

The importance of following established procedure is demonstrated by the fact that the pilot must observe them even when met by unforeseeable conditions. Only a clear showing that he was unable to follow them, or that to do so would involve greater danger, will justify a variation. Such an attempt at justification was made before the California court in Johnson $v$. Western Air Express. ${ }^{30}$ The pilot, while inaking an instrument let-down on the radio range to Burbank airport, encountered unanticipated icing conditions and air turbulence. On the final leg of the approach he was three

26 McCusker v. Curtiss-Wright Flying Service, supra note 2 ; Johnson v. Western Air Exp. Corp., supra note 14. This is probably what was meant by the court in Allison v. Standard Air Limes, supra note 7, when it charged, "If . . . the pilot . . . acted in such a manner as a person of ordinary prudence and caution and skill would use under the same circumstances, he was not neghigent"; see text following note 8 supra.

27 See text at note 57 infra.

28 These procedures are generally too informal to be expressed as rules and are referred to generally as "good flying practice." See Murphy v. Neely, 319 Pa. 437, 179 Atl. 429 (1935). 29 Supra note 2 at $1120-21,162$ Atl. at 592. For another case arising from the same accident, see Boele v. Colomial Western Airways, supra note 17.

3045 C. A. $2 \mathrm{~d} 614,114$ P.2d 688 (1941). 
miles off course and in attempting to return hit a peak in the San Gabriel Mountains. Evidence showed that he failed to turn on the de-icing equipment and that he departed from the prescribed radio procedure by abandoning the radio beam and adopting an average compass heading. The carrier conceded that had conditions been normal, and the pilot able to follow the prescribed procedure, the accident would unquestionably have been due to negligence. But it argued that because of the extraordinary atmospheric situation he was unable to do the things required. The court held it was for the jury to determine whether the pilot, in the exercise of the highest degree of care, was unable to follow the required procedure because the combination of ice and extreme air turbulence made it impossible for him to control the airplane. It found sufficient evidence to justify the finding that the accident occurred because of an act of God rather than the negligence of the pilot.

Since a showing of emergency is necessary to vindicate a deviation from prescribed procedure, where emergency is not shown a non-complying pilot is held to be negligent. Thus, in Goodheart v. American Airlines, ${ }^{31}$ the plaintiff introduced evidence showing that at the time of the crash the airplane was fifty miles off course, proceeding over dangerous and unfamiliar territory at an unsafe altitude. No change in weather conditions along the prescribed route was shown. The defendant established that the airplane was properly equipped and inspected and the pilot was qualified; it offered no excuse for the deviation from the assigned course. The court held that in the absence of sufficient explanation for the deviation, the plaintiff's pleading alleged, and his evidence tended to show, specific acts of negligence entitling him to go to the jury. It would appear from the facts and decision that defendant's proof of utmost care in preparing the airplane for flight would be unavailing if the acts alleged by the plaintiff were proved, since care in preparation in no way disproves a negligent departure by the pilot. The difficulty with this case is that evidence on the sequence of events from the departure of the airplane until the accident was absent, yet the court held it was error to charge the jury that it was not known how the accident happened. Apparently the court felt that since the prescribed route was the safest possible path, any variation was less safe, and if great enough, as in this case, would be sufficient to fix liability without knowledge of the facts immediately preceding the crash. ${ }^{32}$

\section{Errors of Judgment}

The effect of an error of judgment under the circumstances existing during flight is another aspect of the question of the pilot's negligence. A frequently inseparable issue is the question of what circumstances are sufficient to constitute a "sudden emergency." Assuming that the pilot is experienced and skillful, and that his own carelessness was not responsible for his encountering adverse weather, his choice of a faulty course of action

31252 App. Div. 660, 1 N. Y.S. 2 d 288 (1937).

32 See Gill v. Northwest Airlines, 228 Minn. 164, 36 N.W.2d 785 (1949), where court applied the saine rule when the ship crashed into a mountain while the pilot was off course. 
after weighing the surrounding circumstances is not held to be negligence, but rather an error of judgment. As the time available to weigh the existing conditions increases, the choice of a course of action by the pilot should improve. This was demonstrated in McCusker v. Curtiss-Wright Flying Service where the pilot attempted an unscheduled landing at a small field and struck a tree on the final approach. ${ }^{33}$ The purpose of the landing was not clear, since no adverse weather or mechanical failure was shown. Evidence showed that use of landing lights and flare equipment would have disclosed the tree, and a proper approach to the field would have avoided it. The court refused to find the existence of an emergency, and held that the decision of the pilot to land, and his choice of a method to carry it out, were clearly negligent. This holding is sound, since no conditions were shown which required of the pilot a quick decision to avoid a catastrophe.

Even when the pressure from surrounding conditions justifies calling the situation a sudden emergency, the course of action chosen by the pilot must be commensurate with his skill and experience in order to prevent a finding of negligence. This was clearly expressed in Allison v. Standard Air Lines where the pilot, on a flight from Tucson, Arizona, to Los Angeles, ran into an unanticipated fog in San Gorgonio Pass. ${ }^{34}$ He became lost and while apparently attempting to land, crashed. The court charged the jury that a person is not required to exercise the same judgment when faced with a sudden emergency as he would with time to reflect on the situation. It stated that if the pilot used his best judgment under the circumstances and his judgment was approved by competent experts, then the accident would be due to an error of judgment. ${ }^{35}$ With this wide latitude to determine whether the pilot was faced with an emergency, the jury rejected the plaintiff's contention that it was negligent to proceed in any event when the fog arose.

To be compared with this case is Curtiss-Wright Flying Service v. Glose where the pilot encountered an unexpected fog during flight, and, apparently as a result, decided to land at a poor field. ${ }^{36}$ The court found sufficient evidence of negligence when it was shown that other flights by slight deviation in course continued the trip, that other adequate landing fields were in the vicinity, and that the landing was in violation of a Civil Aeronautics Administration provision. The court was not clear as to which acts in themselves were sufficient to justify a finding of negligence. It appears that the decision could be supported either on the ground that an emergency landing was not necessary since the pilot could have flown around the fog; or on the ground that even if an emergency did exist, the choice of a landing field was so poor that it was beyond the scope of allowable errors of judgment.

33 Supra note 2.

34 Supra note 7. See also Thomas v. American Airways, supra note 19, for later accident in same place under very similar circumstances; jury found no negligence.

35. Unfortunately the court of appeals refused to review this instruction on procedural grounds. In the McCusker case, supra note 2 , the court affirmed a refusal to give this instruction on the ground that the pilot may have used his best judgment, have it approved by experts, and still be negligent.

36 66 F.2d 710 (3d Cir. 1933), cert. denied, 290 U.S. 696 (1933). 
The speed of aircraft and the necessity for quick thinking in their operation emphasize the importance of the rule, well settled in negligence law, that a person in an emergency is not required to act with the same amount of thought as would a person with sufficient time to reflect on the situation. But since the ability and judgment of the pilot are so important, the area of emergency should be strictly confined to the truly unforeseeable situations, not created by the acts of the carrier or pilot, and for which no amount of preparation would be adequate. In the early cases, decided when stations for gathering and transmitting meteorological data were comparatively few and when airlines had little experience in contending with the more turbulent forms of atmospheric disturbances, the courts were justified in their frequent finding of unforeseeable èvents and sudden emergencies. Persons choosing the air as a mode of travel were clearly assuming wide risks that sudden weather changes would place the pilot in an emergency situation in which his equipment and experience afforded little protection. Today, airlines and pilots have had many years of experience with the elements, the number and proficiency of weather stations has increased greatly, and aircraft equipment and adverse weather landing devices have improved tremendously. Many of yesterday's unforeseeable events have become today's commonplace occurrences. The notion that a carrier must anticipate the emergencies likely to arise in its business and make preparations to meet them will undoubtedly be given greater weight by the courts as the storehouse of aviation experience grows. ${ }^{3 T}$

So, also, the scope of allowable errors in judgment on the part of the pilot faced with an emergency will gradually be narrowed. The carriers have developed definte procedures for the proper operation of equipment during flight under unfavorable conditions. These procedures have been thoroughly tested and proved by various organizations concerned with aviation, and many have been incorporated into state and federal regulations governing carrier's operations. Already they constitute the bulk of what the crewman must learn. Pilots are intensively trained not only in the function and use of the mechanical aids, but also in the techniques with which to meet climatic or mechanical difficulties. Combatting engine failures and inclement weather is at present largely a problem of acquiring the proper proficiency in the prescribed routines, and will undoubtedly be recognized as such by present day courts.

\section{STATUTORY DEVELOPMENTS}

Concurrent with the development of judicial concepts of the tort liability of air carriers, have been efforts to add umformity to the field through statutes. Various uniform acts have had two primary goals: (1) to fix the standard of tort liability, and (2) to establish uniformity in the regulation and control of carriers, for the purpose of increasing safety.

One of the earliest major efforts to fix the standard of tort liability was

3r This attitude was expressed to a certain extent in Small v. Transcontinental \& Western Air, supra note 22, where the court emphasized the growing knowledge of carriers in detectimg air turbulence in time to warn passengers to fasten their seat belts. 
the promulgation of the Uniform State Law of Aeronautics in $1922 .{ }^{38}$ While the act specifically provided for an absolute liability for injuries to persons and property on the ground, it stated siniply that as to passengers liability should be determined by the rules of law generally applicable to torts occurring on land..$^{39}$ This principle remained unchanged until 1938, when the highly ambitious Uniform Aviation Liability Act was approved by the Commissioners on Uniform State Laws. ${ }^{40}$ It introduced a new theory of absolute liability, ${ }^{41}$ stipulated the limit of recovery for each type of injury, ${ }^{42}$ and provided for compulsory insurance by the carriers. ${ }^{43}$

Dissatisfaction with these acts arose from the first and interest in them waned as time passed. When the failure of the nrovenient became apparent, the commissioners withdrew both from the active list of proposed legislation. ${ }^{44}$ Little was done until the postwar increase in civil aviation again stimulated attempts to formulate a satisfactory statute. In 1946, after much discussion and many revisions, the State Aeronautic Commission or Department Act was submitted to the states for adoption. ${ }^{45}$ This act, which carries on the original idea of applying the rules applicable to torts in other fields ${ }^{46}$ was warmly approved by many groups and has been enacted, with variations, in nearly every state. ${ }^{4 \pi}$

In the regulatory field both the federal and state legislatures have been active in their efforts to add greater substance to the broad standard of care developed by the courts. At the top level is the Civil Aeronautics Act of 1938 authorizing the promulgation of safety regulations by the Civil Aeronautics Board. ${ }^{4}$ Numerous regulations have been issued under the Act, covering inspection and maintenance of aircraft, qualification of pilots, and rules of flight. They are enforced by a system of fines and penalties. ${ }^{49}$ Since the regulations are limited to interstate flight their applicability presents

38 Adopted by the National Conference of Commissioners on Uniform State Laws and the American Bar Association, 9 U. L. A. 17. With variations it was enacted in Ariz., Del., Ga., Hawaii, Idaho, Ind., Md., Mich., Minn., Mo., Mont., Nev., N. J., N. C., N. D., Pa., R. I., S. C., S. D., Tenn., Utah, Vt. and Wis. See 1944 U. S. Av. R. 129 for the enacting statutes in these states. $39 \S 6$.

40 Though approved it was withheld from the states pending study by the Civil Aeronautics Board. War prevented action on the recommendations. See SwEENEX, REPORT To CAB OF A Study of the Proposed Aviation Liability Liggislation (1941).

41 Art. III, § 302 .

42 Id., $\$ 304$.

43 Id., \$ 306 .

44 Handbook of the Nationat Conference of Compartssioners on Untform State Laws (1943).

45 The Act was approved by the National Association of State Aviation Officials (N.A.S. A. O.), the Civil Aeronautics Board, and the Department of Justice. For its history see Schroeder, Activities of NASCO, 1941-1947, 14 J. AIR L. 72 (1947).

$46 \S 2(f)$ : "The liability of the owner or pilot of an aircraft carrying passengers for injury or death to such passengers shall be determined by the rules of law applicable to torts on the lands or waters of this state arising out of such circumstanccs." The provision leaves CAI. CTV. CODE $\$ 2100$, supra note 7 , the applicable section in Cahifornia.

47 See digest of state legislation in 1944 U.S. Av. R. 131, supplemented in 1947 U. S. Av. R. 652, 1949 U. S. Av. R. 799. California enacted the Act in Cal. Stats. 1947, p. 2927; repealing in $\S 26$ the California Air Navigation Act, Cal. Stats. 1929, p. 1874.

4852 STAT. 977 (1938), as amended, 49 U. S. C. § 401-682 (1946).

4014 Code FEd. Regs. 405.1 (1949). 
the usual problem of drawing the line between interstate and intrastate flight. In general, they are held to cover the conventional interstate flight, and all intrastate operation of aircraft which may endanger interstate operations. ${ }^{50}$

This inclusive purview leaves at inost a small sphere of solely intrastate flight within which the state legislatures have exclusive power to prescribe the governing rules. ${ }^{51}$ Pursuant to this power the states have proceeded to legislate, but with such a degree of diversity that no summarization of the statutes would be profitable. In general they are intended to perform for intrastate flight the same functions that the Civil Aeronautics regulations perform in interstate flight. The various uniform acts, inspired primarily frons the desire to eliminate much of the confusion in this area rather than to clarify the standard of tort liability, have been generally unsuccessful. ${ }^{\text {.2 }}$ The recent State Aeronautics Commission or Department Act endeavored to solve the problem by providing for the creation of an independent commission in each state with authority to promulgate rules consistent with the existing federal rules. ${ }^{53}$ The Act would thus have created uniformity by requiring close cooperation with the federal agency. Unfortunately, in passing the act, the legislatures of the various states inserted numerous local variations which tend to nullify its primary purpose. ${ }^{5 / 4}$ The inability of the states to bring uniformity to an area where it is highly essential, coupled with the fact that federal court decisions intimate Congress has authority to regulate all air flight, ${ }^{55}$ indicates that the future may perhaps see complete exclusion of the states from the field of regulation, so that they are left only the power to provide the standard of tort liability for injuries.

Compliance with an applicable regulation does not conclusively demonstate that the required standard of care has been met. Consonant with this rule is the holding that possession of a required pilot's license is not final proof that the pilot was qualified for the particular flight. ${ }^{66}$ Neither is proof of government inspection and approval an irrebuttable showing that the carrier has properly maintained its aircraft. ${ }^{5 \%}$

On the other hand, it is universally held that a violation of an applicable

50 Northwest Airlines v. Minnesota, 322 U.S. 292 (1944) (per Jackson, J., concurring opinion); Rosenhan v. United States, 131 F.2d 932 (10th Cir. 1942), cert. denied, 318 U.S. 790); United States v. Drunini, 55 F. Supp. 151 (D. Nev. 1944); 40 Ors. ATT'y GEN. 15 (1941).

51 Parker v. James Granger, Inc., 4 Cal. 2d 668, 52 P. 2d 226 (1935). The court stated that the federal rules, being inapplicable, should not be presented to the jury in determining if a carrier has been negligent. Some states have specifically adopted portions of the federal regulations.

52 In addition to the acts discussed in text at notes 38 and 40 supra, the commissioners subunitted to the states the UNIFORM AIR LICENSING ACT (1930), 11 U.I.A. 185; UNIFORM AERONAUTTCAT REGULATORY ACT (1935), id. at 173; UNIFORM ATRPORTS ACT (1935), id. at 193. These acts were also withdrawn by the commissioners in 1942, supra note 44.

53 Supra note 45.

54 Black, Uniformity in Air Safety Regulation: Cooperative Federalism Applied, 15 J. AIR I. 181 (1948).

55 Supra note 50.

56 Smith v. Pacific Alaska Airways, 89 F. 2 d 253 (9th Cir. 1937), cert. denied, 302 U. S. 700 (1937).

57 Kamienski v. Bluebird Air Service, supra note 18. 
statute or regulation does not establish liability in itself. ${ }^{58}$ A connection in fact must be shown between the violation and the accident. If this connection is missing the violation is of no consequence in determining negligence. Since the regulations are intended primarily to promote the safety of all aeronauts, little difficulty is encountered in bringing the passengers within the class of persons designed to be protected; hence, the major problem centers around the question of the type of risk covered by the regulation. The problem is exemplified in a recent case where the plaintiff alleged that the pilot had only a private pilot's license and was not qualified to carry passengers, and that this was negligence in itself. The court rejected this contention, emphasizing that the pilot may have been perfectly competent to fly the airplane. ${ }^{59}$ Although the court spoke in terms of proximate cause, proper analysis shows the statute attempts to avoid the risk of injury from mcompetent pilots. It does not establish that a pilot who has failed to procure a license is incompetent; therefore, absence of a license was completely immaterial to the issue of negligence.

Even when a connection between the violation and the accident is shown, the courts are not in harmony as to the effect of the violation in a particular case. One line of authority is represented by Thomas v. American Airways, where the court charged that a violation, when unjustified, is negligence without other proof. ${ }^{\circ}$ The other line of authority, which appears to be in the minority, holds that a violation is merely evidence of negligence which the jury may consider with the other facts in determining whether the carrier has complied with the established standard. ${ }^{61}$

\section{CONCLUSTON}

When the airlines were endeavoring to establish themselves in the transportation field it was widely felt that a heavy burden of liability would stifle their growth. The courts, conscious of such a possibility, gave expression to it by requiring no greater assurances of safety for passengers than the carriers were capable of providing. Unfortunately this solicitous attitude in many cases permitted the carrier to escape liability by unduly emphasizing the problems of navigating the atmosphere. As experience witl aviation accident cases grew the courts began to show a maturer understanding of the dangers a carrier is capable of surmounting. Instances of lagging appreciation of the changes aviation development has wrought are becoming fewer. While the standard of utmost care is firmly embedded in statutes and decisions, the circumstances which determine whether that

58 Morrison v. Le Tourneau Co. of Georgia, 138 F. 2d 339 (5th Cir. 1943) ; Braman-Johnson Flying Service v. Thompson, 167 Misc. 167, 3 N. Y.S.2d 602 (1938) (use of experimental propellor).

59 Ibid.

${ }^{60}$ Supra note 19. Accord: American Airlines v. Ulen, 87 U.S.App. D. C. 307, 186 F. 2d 529 (D. C. Cir. 1949) (violation of regulation fixing minimum clearance of obstacles on course); Morrison v. Le Tourneau Co. of Georgia, supra note 58.

61 Conklin v. Canadian Colomal Airways, supra note 7 (instruction on effect of violation of regulation); Ziser v. Colonial Western Airways Inc., 1931 U. S. Av. R. 73 (1932), aff'd., stipra note 2 (jury instruction). See PROSSER, TORTS 274 (1941), for reasons for the varying effect given by courts to the violation of statutes. 